\title{
Vegetative propagation of elite Eucalyptus clones as food source for honeybees (Apis mellifera); adventitious roots versus callus formation
}

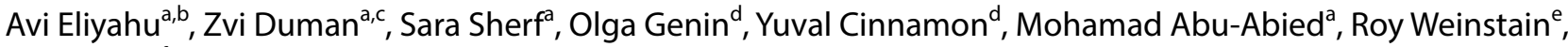 \\ Arnon Dag $^{f}$ and Einat Sadot ${ }^{\mathrm{a}}$

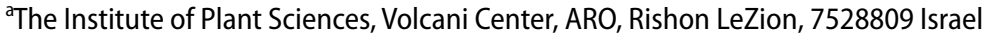

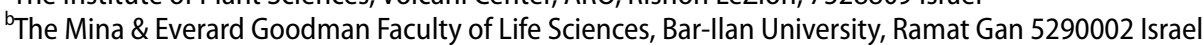 \\ 'The Robert H. Smith Institute of Plant Sciences and Genetics in Agriculture, The Robert H. Smith Faculty of Agriculture, Food and Environment, \\ The Hebrew University of Jerusalem, Rehovot 7610001, Israel \\ ${ }^{\mathrm{d}}$ The Institute of Animal Sciences, Volcani Center, ARO, Rishon LeZion, 7528809 Israel \\ 'The School of Plant Sciences and Food Security, The George S. Wise Faculty of Life Sciences, Tel Aviv University, Tel Aviv, 6997801 Israel \\ ${ }^{f}$ Gilat Research Center, The Institute of Plant Sciences, Volcani Center, ARO, 8510500 Gilat, Israel
}

\begin{abstract}
Summer and autumn in Israel are highly arid with not enough plants in bloom offering nectar and pollen to support the local apiary. This leads to decline in colony health and honey production. To increase food sources for honeybees, we initiated a project to clone elite Eucalyptus trees exhibiting constant and rich blooming from late summer to early winter. We induced adventitious roots from cuttings of two mature Eucalyptus trees of which nectar production and honeybees' attraction was measured: Eucalyptus brachyphylla and Eucalyptus $\mathrm{x}$ trabutii. During the rooting process, a high frequency of cylindrical callus formation instead of roots was obtained. To shed light on the inner anatomy of the callus chunks, we compared their cell organization and cell-wall composition to those of roots. Whereas in the root, cells were organized in circumferential symmetry, no symmetry was found in the callus. Instead, a more chaotic accumulation of meristematic-like cells with sporadic clusters of tracheary elements laid in different directions were observed. The outer cell layer of the callus often included swollen cells with thin cell walls. Most callus cells stained more strongly for cellulose and lignin than cells in the root meristem. In addition, specific antibodies to methylesterified and de-methylesterified pectin showed differential staining of callus vs. root cells indicating cell wall differences. Strikingly, roots were seen to differentiate from the chaotic cell organization of the callus, albeit at low rates. Further investigation of the cellular and molecular mechanisms underlying callus formation, are required.
\end{abstract}

\section{ARTICLE HISTORY}

Received 30 June 2019

Accepted 9 September 2019

\section{KEYWORDS}

Adventitious roots; callus; Eucalyptus; honeybee; cell wall; cellulose; pectin

\section{Introduction}

Bee forage plants provide pollinators with nectar, which contains carbohydrates, and pollen, which contains proteins, fatty acids, vitamins and minerals. A balanced diet that contains all of these components is crucial for the development, lifespan and immune fitness of the honeybee (Apis mellifera) and of the colony as a superorganism (Nicolson 2011). In recent decades, the disappearance of honeybees as a result of dispersal of the varroa mite (Varroa destructor), the massive application of pesticides on agricultural crops, climate change, and the reduction in natural blooming, has raised serious concern (Goulson et al. 2015). The hardest time of year for Israeli apiaries is at the end of the summer until early winter, when most of the local bee forage plants do not bloom. Without artificial supplementary feeding during this time, beehives suffer from malnutrition. Since the honeybee serves as a main pollinator in various ecosystems and for important agricultural crops, there is an interest in keeping this species vital and wealthy around the year.

The genus Eucalyptus is an important food source for various pollinators due to its rich blooming, high nectar production, and large number of pollen grains 
in every flower (Moncur and Boland 1989). Moreover, the blooming time of a Eucalyptus flower is relatively long, ranging from 4 to 18 days, depending on the species (Davis 1997). Since anthesis occurs gradually, the blooming period of a given Eucalyptus tree can last from a few weeks to a few months. Protein-content analysis performed on pollen grains from 19 Eucalyptus species from different sites in Australia found a crude protein percentage ranging from 20.5 to $30.1 \%$ (Somervill 2001). Compared to the protein content reported for pollen grains of citrus (18.5\%), lavender (Lavendula spp.; 19.4\%), almond (Prunus dulcis; 12.4\%), maize (Zea mays; 14.9\%) and sunflower (Helianthus annuus; $13.8-15 \%)$, the protein content of Eucalyptus pollen grains is relatively high, and meets the honeybee's protein nutritional demands (Somervill 2001).

Many Eucalyptus species were introduced to Israel decades ago for honeybee pasture purposes, as well as for forestry. Some of the Eucalyptus species conformed to arid areas in Australia and thus are well adapted to the Israeli growth conditions. Beekeepers and ecologists report on a high variety in the blooming traits of Eucalyptus trees within the same species, including blooming timing and intensity, and attraction to honeybees. Studies on Eucalyptus cladocalyx populations in the arid zone of the Atacama Desert in Chile have shown that flowering traits are highly affected by genetics (Cané-Retamales et al. 2011). Since most Eucalyptus trees in Israel originate from seeds, we assume that the variability seen in Eucalyptus plantations is due at least in part to their genetics. In addition, evidence in recent years has shown significant variability in the responses of Eucalyptus trees from the same species to drought stresses, which are becoming more relevant in the face of global climate change (Li and Wang 2003). Taken together, the clonal propagation of elite Eucalyptus trees for honeybee pasture is well-justified.

In vegetative propagation of desired clones, plants are duplicated asexually, with the aim of achieving progeny that are genetically identical to the parent. This requires the induction of adventitious roots (ARs) from cuttings. However, because woody plants tend to lose their rooting ability during the change from juvenile to mature phase (Diaz-Sala 2014; Hackett 1985; Poethig 1990, 2010; Riov et al. 2013; Vilasboa et al. 2018), it is often very difficult to clone trees with known blooming traits. The change from juvenile to mature phase is very prominent in some Eucalyptus trees, (Johnson 1926), thus, Eucalyptus trees serve as a good model system for research into the loss of rooting ability during adulthood (Abu-Abied et al. 2012, 2014; Levy et al. 2014; Vilasboa et al. 2018).

Here, we selected two elite Eucalyptus trees based on their exceptional nectar secretion and honeybees' attraction, cloned them, prepared mother plants for further propagation, and payed specific attention to the formation of $A R$ and callus from their cutting bases. While callus is defined as unorganized cell mass (Ikeuchi et al. 2013), we found that callus with a specific cylindrical shape was often formed alongside AR formation. The differential anatomy and cell-type populations in the callus were compared to those in the roots using various microscopy methods.

\section{Materials and methods}

\section{Materials}

All materials were from Sigma Aldrich Israel, unless otherwise specified.

\section{Measurements of nectar and honeybee visits}

The two Eucalyptus trees, $E \times$ trabutii and E. brachyphylla, are growing in Kfar Pines, Israel. Nectar secretion and honeybee visit measurements were performed as follows: 1 day prior to each observation, 10 flowers in the preanthesis phase were chosen, marked and bagged with a white organza bag (50 mesh) to prevent access of pollinators to the flower. The preanthesis phase was defined as the time when the operculum has fully disengaged from the flower receptacle, but still covers the anthers, 1 day before the operculum falls and the flower opens completely (Fig. 1C) . In the next 4 days, starting at sunrise and ending at sunset, the following data were collected from the marked flowers every $2 \mathrm{~h}$ : nectar volume (NV) was measured using a glass micropipette (Drummond Scientific, USA), and its sugar concentration (NC) was measured using a handheld refractometer (Atago Japan). The NV was multiplied by the NC for each flower for each measurements and the sum of it during 4 days was calculated. The average of sugar production between 10 flowers during 4 days is the total floral sugar yield per $4 \mathrm{~d}$ (Table 1 and Supplementary Tables S1 and S2). To estimate the flowering intensity $(\mathrm{FI})$, i.e., the number of flowers that open during the blooming season, fresh opercula were sorted from two or three $50-\mathrm{cm}^{2}$ area patches under each tree and counted (operculum density; OD). The average 

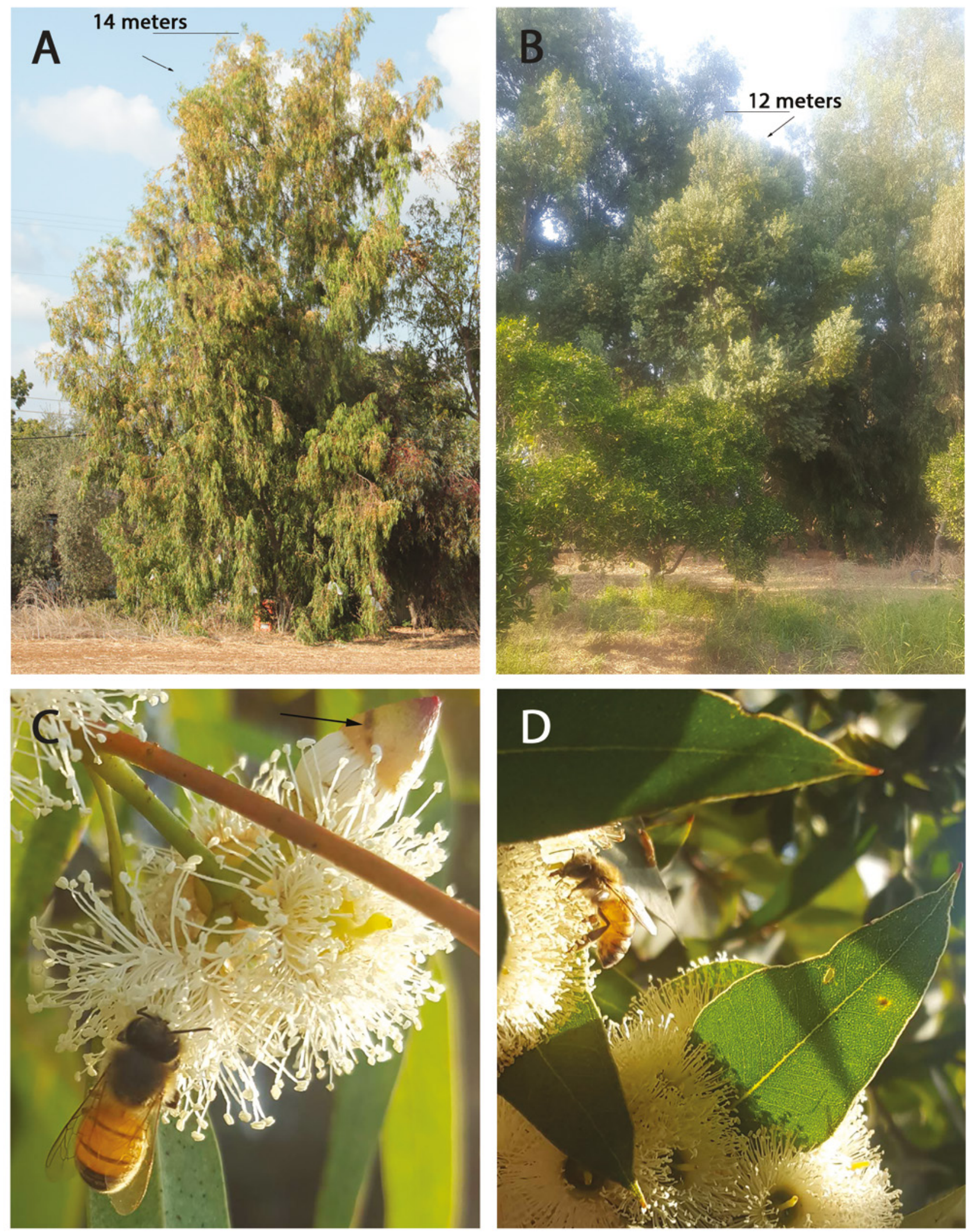

Figure 1. The selected trees. (A) $E \times$ trabutii tree. (B) E. brachyphylla tree. (C) $E \times$ trabutii flowers. Arrow indicates a preanthesis-stage flower, such as those bagged before nectar measurements. (D) E. brachyphylla flowers. 
Table 1. Sugar production, estimated honey yield, and attractiveness to honeybees.

\begin{tabular}{|c|c|c|}
\hline & Extrabutii & E. brachyphylla \\
\hline $\begin{array}{l}\text { Total floral sugar yield } \\
\text { per } 4 d(\mathrm{mg})\end{array}$ & $26.18 \pm 9.59(\mathrm{~N}=10)$ & $19.69 \pm 12.89(\mathrm{~N}=10)$ \\
\hline Opercula per $50 \mathrm{~cm}^{2}$ & $2039 \pm 941(\mathrm{~N}=3)$ & $2673 \pm 29(N=2)$ \\
\hline Tree area $(\mathrm{m})$ & $9 \times 8$ & $7 \times 7.5$ \\
\hline $\begin{array}{l}\text { Seasonal sugar yield } \\
\text { per tree }(\mathrm{kg})\end{array}$ & 30 & 22 \\
\hline Trees per 0.1 ha & 9 & 20 \\
\hline $\begin{array}{l}\text { Calculated sugar yield for } \\
0.1 \text {-ha clonal } \\
\text { plantation }(\mathrm{kg})\end{array}$ & 275 & 442 \\
\hline $\begin{array}{l}\text { Calculated honey yield for } \\
0.1 \text {-ha clonal } \\
\text { plantation }(\mathrm{kg})\end{array}$ & 327 & 526 \\
\hline $\begin{array}{l}\text { Average nectar-collector } \\
\text { visits per } 5 \text { min on one } \\
\text { flower cluster }\end{array}$ & $8.65 \pm 5.55$ & $7.76 \pm 4.66$ \\
\hline $\begin{array}{l}\text { Average pollen-collector } \\
\text { visits per } 5 \mathrm{~min} \text { on one } \\
\text { flower cluster }\end{array}$ & $6.95 \pm 5.01$ & $6.79 \pm 4.65$ \\
\hline
\end{tabular}

number was multiplied to fit the total area under the tree (TA) which was measured using a measurement tape.

The sugar yield of each tree was estimated according to the following equations:

$\begin{gathered}\text { Total floral sugar production } \\ \left(5 \text { measurements per day } \times_{4} \text { days }\right)\end{gathered}=\frac{\sum N V \times N C}{10}$

$F I=O D \times \frac{T A}{50 \mathrm{~cm}^{2}} \times 2$

$\begin{gathered}\text { Tree sugar production } \\ (\text { blooming season })\end{gathered}=\left[\begin{array}{c}\text { Total floralsugar production } \\ \text { (one flower per } 4 \text { days })\end{array}\right] \times F$

Potential honey yield $=$ Tree sugar production $\times 1.19$

The number of honeybee visits to one flower cluster was counted for $5 \mathrm{~min}$ in three replicates every $2 \mathrm{~h}$. Bees were distinguished as nectar collectors and pollen collectors according to the presence of pollen grains in their corbiculae.

\section{AR induction}

Branches were excised from mature trees in the field, placed in a humidified cooler box and brought to a climate-controlled greenhouse within $2 \mathrm{~h}$. Each cutting, $7 \mathrm{~cm}$ long, included three nodes with only two leaves remaining at its apical end. Two-thirds of each blade was excised to minimize evapotranspiration. The cutting bases were submerged for $1 \mathrm{~min}$ in $6 \mathrm{~g} / \mathrm{L}$ indole3-butyric acid potassium salt (K-IBA) supplemented with experimental rooting enhancers at a concentration of $100 \mu \mathrm{M}$. Enhancer 52 was 4-chlorophenoxyacetic acid (4-CPA) conjugated to D-tryptophan, and compound 53 was 4-CPA conjugated to L-tryptophan. In addition, the leaves were sprayed with $100 \mu \mathrm{M}$ of each rooting enhancer in the presence of $0.05 \%$ Triton X-100 as surfactant. Stock solutions of the experimental rooting enhancers were $100 \mathrm{mM}$ in DMSO. The cuttings were planted in rooting medium containing peat, vermiculite and polystyrene flakes at a ratio of 1:2:3 respectively, on a $25^{\circ} \mathrm{C}$ heated rooting table, with sprinklers activated for 10 seconds every 10 minutes creating $90 \%$ humidity. Fungicides were applied to the rooting media on a weekly basis. Rooting percentage, number of roots per cutting and root length were measured after 1 and 2 weeks and after 1 and 2 months.

\section{Cell-wall staining}

Elongated callus or root samples were manually sectioned, fixed for 24 hours, in $4 \%$ paraformaldehyde in PBS (Biological Industries, Beit Haemek, Israel) supplemented with $150 \mu \mathrm{g} / \mathrm{mL}$ ascorbic acid, $1 \mathrm{mg} / \mathrm{mL}$ DTT and $10 \mathrm{mg} / \mathrm{mL}$ PVP to prevent tissue oxidation. The samples were washed three times in PBS and cleared using ClearSee as previously described (Kurihara et al. 2015). Briefly, samples were incubated in ClearSee $(10 \% \mathrm{w} / \mathrm{v}$ xylitol, $15 \% \mathrm{w} / \mathrm{v}$ sodium deoxycholate, $25 \%$ w/v urea in $\mathrm{H}_{2} \mathrm{O}$ ) at room temperature under gentle agitation for several days. ClearSee solution was replaced daily. The samples were stained for cell walls as previously described (Ursache et al. 2018). Samples were incubated for $5 \mathrm{~min}$ in $0.5 \%(\mathrm{w} / \mathrm{v})$ Auramine $\mathrm{O}$, rinsed twice with ClearSee and then placed on a slide with $0.1 \%(\mathrm{v} / \mathrm{v})$ calcofluor solution containing $1 \mathrm{gr} / \mathrm{L}$ calcofluor white and 0.5gr/L Evans blue (Sigma). The dyes were diluted in ClearSee.

\section{Immunostaining}

Elongated callus finger or root samples were manually sectioned, fixed for $1 \mathrm{~h}$ at room temperature in freshly prepared $8 \%$ paraformaldehyde in PME buffer containing $100 \mathrm{mM}$ PIPES pH 6.89, $5 \mathrm{mM} \mathrm{MgSO}_{4}, 0.5 \mathrm{mM} \mathrm{EGTA}$, $1 \%$ Triton $X-100$. The samples were then rinsed three times (15 min each) in PME buffer. For blocking, the samples were incubated in PBS containing $3 \%(\mathrm{w} / \mathrm{v})$ 
bovine serum albumin (BSA) for $1 \mathrm{~h}$. This was followed by incubation with the antibodies JIM5 and LM20 diluted 1:10 in PBS/BSA overnight in a humidified chamber. The next day, samples were washed three times with PBS, 15 min each, and incubated for $1 \mathrm{~h}$ with the secondary antibodies-goat anti-rat antibodies conjugated to Alexa fluor 488 (Jackson ImmunoResearch Laboratories, West Grove, PA, USA). Then three washes with PBS were performed, with $0.1 \%$ calcofluor solution added to the third wash as an internal standard. An additional wash with distilled water preceded mounting in Fluoro-Gel mounting medium with DABCO antifade solution (Electron Microscopy Sciences, USA).

\section{Confocal microscopy}

Samples were imaged with an Olympus IX81/FV500 laser-scanning microscope. Calcofluor and Auramine $O$ were excited with the $405 \mathrm{~nm}$ laser. For calcofluor emission, a BA430-460 filter was used, and for Auramine O, IF 530. The samples stained for pectin were imaged using excitation at $488 \mathrm{~nm}$ and BA505-535 for emission.

\section{HREM (High Resolution Episcopic Microscopy)}

Tissue was fixed for 1 week in FAA (50\% ethanol, 10\% formaldehyde, $5 \%$ acetic acid, v/v), rinsed for 1 day in $75 \%$ ethanol and then serially dehydrated in $85 \%$, $95 \%, 100 \%$ ethanol for 1 day each. The tissue was then incubated for 10 days with JB-4 (Electron Microscopy Sciences) containing $0.27 \%(\mathrm{w} / \mathrm{v})$ eosin and $0.056 \%$ $(\mathrm{w} / \mathrm{v})$ acridin orange dyes at $4^{\circ} \mathrm{C}$ with gentle agitation as previously described (Izhaki et al., 2018). Samples were positioned and mounted in plastic molds and sectioned using the HREM system (Indigo Scientific, Baldock, UK); Perfectly aligned 2826 images, representing $2.6 \mu \mathrm{m}$ thick sections, were stacked using Fiji software (Schindelin et al. 2012). Three-dimensional reconstruction was performed using Amira software (FEl, Hillsboro, OR, USA).

\section{Image analysis}

For measurement purposes, all image-acquisition parameters were equal. Fiji software was used for length and width measurements of cells as well as for fluorescence intensity. While three-way junctions were circled to define regions of interest, cell circumference was marked with straight lines. Normalization was performed by dividing fluorescence intensity of the Alexa fluor 488 by that of calcofluor in the same pixels.

\section{Statistical analysis}

Statistical analysis was performed using t-test with p-value threshold equals 0.05 with JMP PRO 14.0.0.

\section{Results}

\section{Selection of elite trees}

To support the honey industry in Israel, we selected for trees that flower during the autumn until early winter when hardly any other plants are in bloom. The desired properties for the selected trees were intense and robust blooming, high sugar production through nectar secretion, and high attraction to honeybees. Following the recommendations of an experienced beekeeper, we focused on two individual Eucalyptus trees: Eucalyptus $\times$ trabutii (Fig. 1A, C) and Eucalyptus brachyphylla (Fig. 1B, D).

To evaluate the trees' sugar production, we conducted an observation over 4 days in the middle of their blooming season, as previously described (Lupo and Eisikowitch 1990). The blooming season was documented by the beekeeper and by our own inspection to be from August to November for $E \times$ trabutii, and November to January for E. brachyphylla. Accordingly, in 2018, measurements were performed on October 8-11 for the $E \times$ trabutii and on November 19-22 for E. brachyphylla. We have found that an average flower of $E \times$ trabutii produced $26.18 \pm 9.59 \mathrm{mg}$ sugar and that of E. brachyphylla produced $19.69 \pm 12.83 \mathrm{mg}$ sugar in four days (Table 1 and Supplementary Table S1). To estimate how many flowers bloom on the trees during one blooming season, we examined the number of opercula under the trees (Table 1). Accordingly, it was estimated that in $E$. $\times$ trabutii, approximately 1.17 million flowers, and in E. brachyphylla, approximately 1.12 million flowers bloom in one blooming season.

Based on these numbers, we provided a putative estimation of sugar production for these trees over one blooming season (Table 1). Assuming that honey contains $81 \%$ sugar, we calculated the honey yield per season for 0.1 ha with $E \times$ trabutii or E. brachyphylla trees (Table 1). Similar work performed in Israel examining Eucalyptus erythrocorys found that one tree can yield $1.1 \mathrm{~kg}$ of honey and that a plantation of 62 trees on 0.1 
ha can produce $72 \mathrm{~kg}$ of honey under good conditions (Lupo and Eisikowitch 1990), which is 4.5- and 7.3-fold less than the estimated honey yields of $E \times$ trabutii and $E$. brachyphylla, respectively (Table 1 ), under the above-described conditions.

Regarding the honeybee visits, the first and very clear observation was a loud honeybee hum around these trees during the hours of observation, indicating a high level of attractiveness. However, we wanted to quantify this attractiveness and the preference for the food reward offered by the trees. Therefore, we counted the mean number of honeybee visits to one flower cluster over 5 min during the day. Mean honeybee visits per $5 \mathrm{~min}$ for an $E \times$ trabutii flower cluster was 14.41 \pm 7.44 , and for E. brachyphylla, $13.31 \pm 6.87$ (Table 1). In both trees, about half of the visiting honeybees collected nectar, and the rest collected pollen (Table 1). In comparison, pollinator visits to Eucalyptus costata flowers in Victoria, Australia ranged between 1.5 to 5 visits per cluster over 5 min (Horskins and Turner 1999). An examination of honeybee visits to Eucalyptus species performed in Israel revealed the following number of visits per flower, per hour: E. camaldulensis $4.5 \pm 4.14$; E. kruseana $0.96 \pm 1.26$; E. leucoxylon $9 \pm 4.5$, and $E$. tor wood 7.14 \pm 5.16 (Keasar and Shmida 2009). Adjusting our data to this scale and assuming that one cluster of flowers in the trees that we examined consists of about 15 flowers, it is suggested that the two trees chosen for our study are considerably attractive to honey bees.

\section{Vegetative propagation of elite trees}

A low rate of rooting of the cuttings from the mature trees was expected (Abu-Abied et al. 2012; Vilasboa et al. 2018). Therefore, as a first step, we sought to create a small collection of mother plants. We harvested cuttings from mature trees, and treated them with K-IBA mixed with experimental rooting enhancers based on synthetic auxins. While rooting percentages were low (5-8\%; data not shown), this yielded several mother plants from each tree, from which cuttings were harvested for continued experiments. Of note, the rooting rate improved when the cuttings originated from the mother plants grown in the greenhouse (Fig. 2). Cuttings from $E$. brachyphylla and $E \times$ trabutii exhibited up to $45 \%$ rooting (Fig. 2). We also noticed different rooting kinetics between the two trees: cuttings from $E \times$ trabutii rooted relatively rapidly, after 1-2 weeks, but rooted cuttings had difficulty undergoing hardening and survival rates were low (about 50\%). In contrast, it took 1-2 months for cuttings from E. brachyphylla to root, but survival was close to $100 \%$ (data not shown). Whereas in E. brachyphylla, the average root number was around 4 and 2 following K-IBA or K-IBA combined with the new rooting enhancers, respectively (Fig. 2B), in $E \times$ trabutii, it was around 5 for all treatments (Fig. 2F). The longer roots obtained for E. brachyphylla after treatment with the new enhancers (Fig. 2C) suggested earlier root formation. In addition, root induction resulted in the formation of callus, often and more seldom in E. brachyphylla and $E \times$ trabutti cuttings, respectively (Fig. 2A, E, D, H).

Callus formed in E. brachyphylla and in $E \times$ trabutii often developed into a cylindrical shape (Figs 2D, 3A) resembling a root. We examined the differences and similarities between the cells populating the callus and those found in a genuine root which allow anisotropic growth.

\section{Shapes and cell-wall features of cells in roots vs. callus}

Imaging of longitudinal sections of the root tip (Fig. 3B) revealed a typical well-organized root tip with rootcap cells staining mainly for cellulose, flanking a meristem containing cells with a thin primary cell wall with very low staining. The meristem was encircled by an arc of more lignified cells, separating it from the root cap. The other cell lineages emerging from the meristem stained for both lignin and cellulose. Despite the similarity in the organs' general shape, the longitudinal section of the tip of the callus (Fig. $3 \mathrm{C}$ ) revealed a completely different cell organization. The first very clear difference was the tip shape, which was rounder and flatter than the sharp root tip. In addition, all cells looked similar in shape, and staining intensities both for cellulose and lignin were more or less equal for all cells in the callus.

Root hairs are specific cells that are expected to be present in the root; they are extensions elongating from epidermal cells, designed to absorb water and nutrients from the soil. Imaging of the transverse sections of the E. brachyphylla root (Fig. 3D) clearly showed the root hairs in the section circumference. These were typical, numerous, narrow and straight. In sharp contrast, in the callus transverse sections, we saw either many swollen cellular extensions (Fig. 3E) or a single normal-like root hair (Fig. 3F) emerging from 


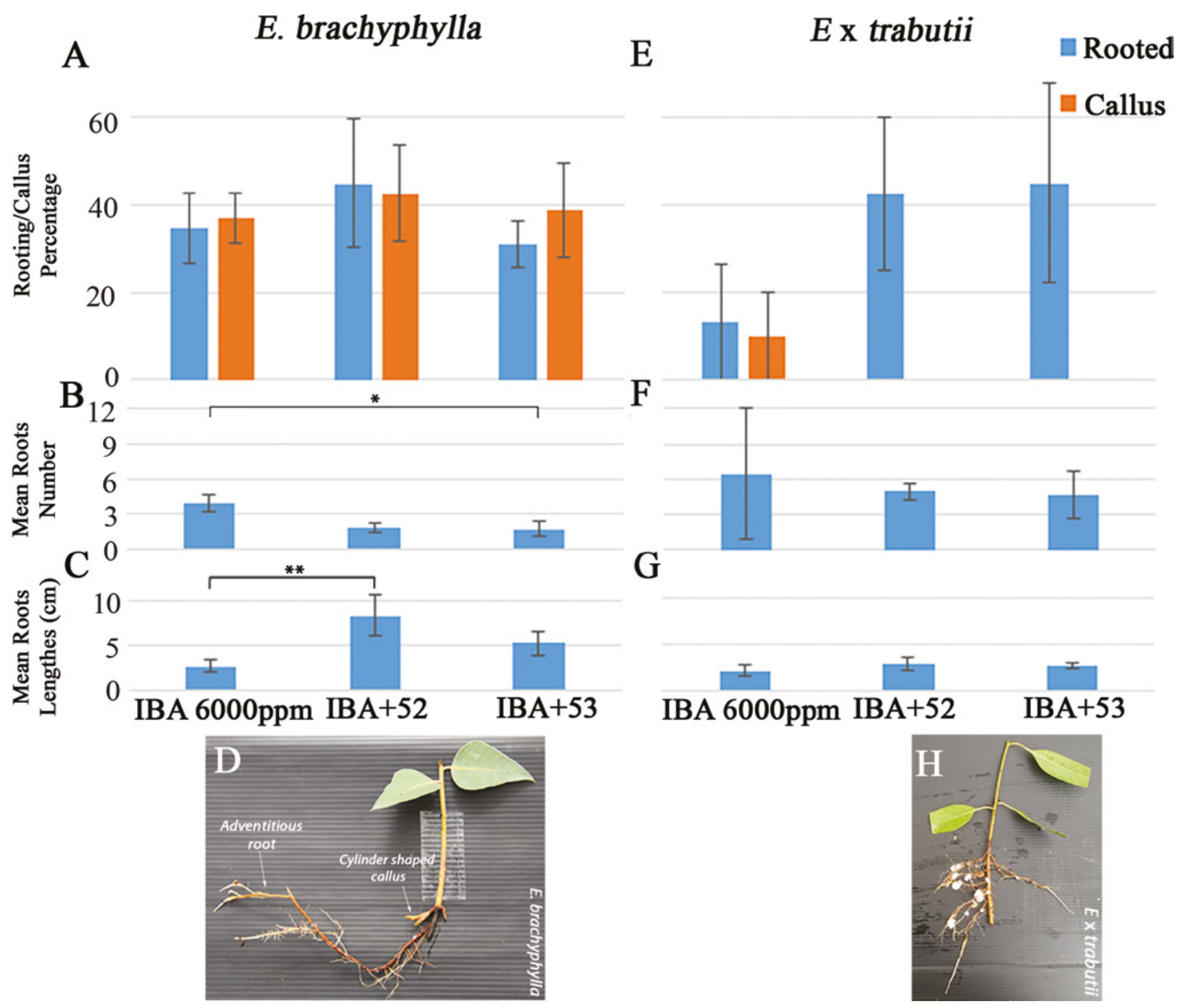

Figure 2. Rooting of cuttings from E. brachyphylla (A-D) and $E \times$ trabutii $(\mathrm{E}-\mathrm{H})$. (A,E) Rooting and callus-formation rates. Bars represent averages of 3 repeats. $(B, F)$ Mean root number per cutting. $(C, G)$ Mean root length per cutting. $(D, H)$ Representative rooted cuttings (t-test; $\left.{ }^{*} P<0.05 ;{ }^{* *} P<0.01\right) .52$ and 53 are rooting enhancers.

the outer layer of the cells. This suggested a problem with epidermis differentiation and/or polar growth of the root hair tip.

Another striking difference was related to differentiation of the xylem tracheary elements. Whereas in transverse sections of the root, the vascular tissue appeared in the middle, exhibiting quintuple symmetry and a coherent growth axis parallel to the growth axis of the root (Fig. 3G), in the callus, although always in the inner layers, some sporadic clusters of tracheary elements were observed, but with no coherent directions among the cells (Fig. $3 \mathrm{H}, \mathrm{I})$. In some cases, the cluster of tracheary elements was surrounded by what seemed to be a coordinated cell arrangement forming a ring-like structure (Fig. $3 \mathrm{~J}$ ). In addition, in some cases, we could detect rectangular cells organized in narrow parallel columns that were reminiscent of cambial cells (Fig. 3K). Therefore, the unorganized chaos was interspersed with groups of cells forming patches of specific-like tissues. Surprisingly, on rare occasion we could differentiate what seemed to be a root-like organ with organized epidermis and a sharp tip-like shape (Fig. 3L).

The details described in Fig. 3 do not explain the anisotropic growth of the callus, leading to its cylinder-like shape. To gain more information, we focused the confocal microscope laser beam on the outer cell walls of the epidermis in longitudinal sections. This enabled imaging the orientation of the cellulose microfibrils following staining with calcofluor dye (Fig. 4). 

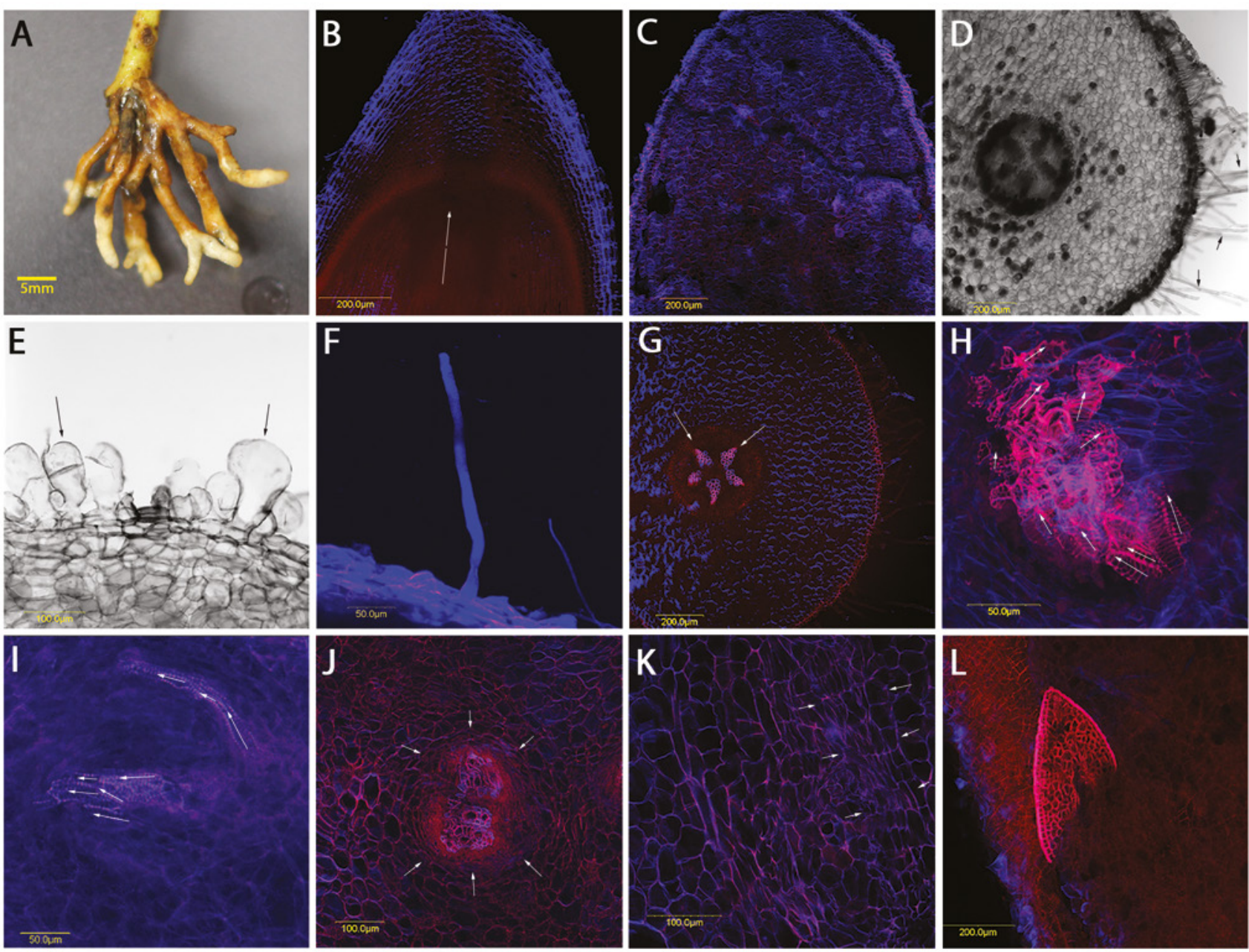

Figure 3. Differences in cell shape and organization between callus and roots. (A) Cylinder-shaped callus formed following induction of E. brachyphylla cutting to root using K-IBA. (B-L) Hand sections of callus and roots from Ex trabutii and E. brachyphylla. Blue: cellulose (calcofluor); red: lignin and suberin (Auramine 0); gray-scale images - DIC (differential interference contrast). (B) E. brachyphylla root tip, longitudinal section. Arrow shows meristematic zone. (C) E. brachyphylla callus tip, longitudinal section. (D) E. brachyphylla root, transverse section. Arrows indicate root hairs. (E) Swollen root hairs or epidermal cells imaged in the circumference of an E. brachyphylla callus. (F) A single root hair-like cell emerging from the outer-layer cells of an $E \times$ trabutii callus. (G) E. brachyphylla root, transverse section. Arrows indicate vascular bundles. $(\mathrm{H}) E \times$ trabutii callus, transverse section. Arrows indicate the various orientations of the tracheary elements. (I) $E \times$ trabutii callus, longitudinal section. Arrows indicate orientations of the tracheary elements. (J) E. brachyphylla callus, transverse section. Arrows indicate organized cells around the tracheary element bundle. (K) Cambium-like cells in $E \times$ trabutii callus. Arrows indicate files of cells in organized columns. (L) E. brachyphylla callus, longitudinal section, showing differentiation of what seems to be a root tip within the callus.

As expected, the direction of the cellulose microfibrils in the root epidermal cells was perpendicular to the growth axis (Fig. 4A). Interestingly, no particular organization of cellulose microfibrils was resolved in the outer cell layer of the callus (Fig. 4B), although specific oval gaps in the calcofluor stain were detected in their elongated axis perpendicular to the callus growth axis. This trend was consistent, even when the cell direction did not seem to be aligned with the growth axis (Fig. 4B). When we measured the ratio of cell length to width, we found that while in the root, the length was more than 2.5 times the width and all cells were similarly oriented, in the callus, the average length was only 1.5 times the width and the cells' direction did not coordinate with the growth axis or with each other. It is not clear whether the coherent gaps in calcofluor staining were formed before or after the cells acquired their final different shapes, or whether these contributed to the elongated cylindrical shape of the whole organ.

The differences in cellulose staining in the cell wall led us to check pectin, known to be a major load-bearing 

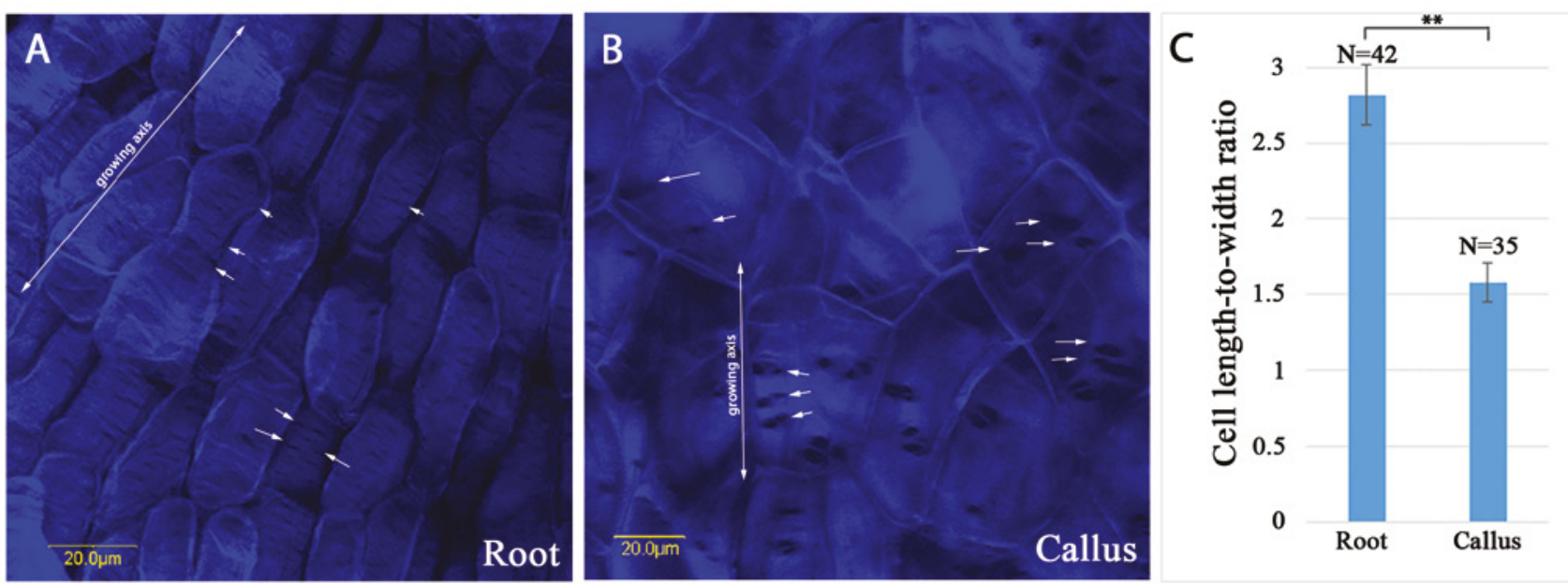

Figure 4. Cellulose microfibril orientation in the outer cell wall of the epidermis of E. brachyphylla root (A) and callus (B). Blue color indicates cellulose (calcofluor). (C) Quantitative analysis of the cell length-to-width ratio in the root and callus (t-test; $\left.{ }^{* *} \mathrm{P}<0.01\right)$.

component of plant cell walls (Cosgrove, 2016). Transverse sections of $E$. brachyphylla root and callus were fixed and stained with the antibodies JIM5 for de-methylesterified homogalacturonan and LM20 for homogalacturonan (Knox et al. 1990; Verhertbruggen et al. 2009), together with calcofluor as an internal standard. It was found that whereas JIM5 fluorescence intensity was equal between root and callus, that of LM20 was significantly lower in the root (Fig. 5A-E). In addition, JIM5 fluorescence was mainly restricted to the three-way junctions between cells which looked tightly closed in the root. In contrast, in the callus, JIM5 stain was spread throughout the cell wall and many of the three-way junctions were open, forming a green triangle stained with JIM5 antibody (Fig. 5A,C). The specific three-way junction stain of JIM5 was quantified by comparing fluorescence intensities in the junctions and the rest of the wall (Fig. 5F). The ratio of the normalized mean fluorescence intensity of JIM5 measured in the three-way junctions divided by that measured in the other areas of the cell circumference was 6.3 in the root, and 0.67 in the callus (Fig. 5F). Whereas in the root, the normalized fluorescence of LM20 was sporadically and equally distributed along the cell walls, in the callus, a 2.2-fold increase in LM20 normalized fluorescence could be observed in the cell circumference compared to the three-way junctions.

The finding of a root-tip-like structure inside the callus (Fig. 3L) led us to closely examine the frequency of possible root emergence from the callus. As mentioned, the callus formed from the treated cuttings had a cylindrical shape that together composed a branching coral-like structure. The average number of "finger tips" counted in callus formed from a cutting was 19.35 \pm 1.79 ( $\mathrm{SE} ; \mathrm{N}=32$ ). When looking for roots emerging from callus, we found roots in $6 \%$ of the cuttings that developed callus. Among these cases, only one callus branch per cutting showed root emergence.

These numbers confirmed that root emergence from the callus, although not very common, does occur. We assumed that one of two scenarios underlie this phenomenon: the first is that the root originates from cambium cells in the cutting base and paves its way out through the callus; the second is that the root differentiates in the callus. To distinguish between these two options, we took advantage of a HERM device which is a microscope combined with a microtome that dissect and image simultaneously section after section (Izhaki et al. 2018). A callus finger from which a root had emerged (Fig. 6A), was fixed, stained, and imaged using HREM (Fig. 6B). The raw data were processed and analyzed to create a three dimensional view (Fig. 6). This enabled us to follow the origin of the root throughout the tissue. Looking at the upper sections of the callus, we could see circumferential organization of the cells (Fig. 6C). This organization disappeared in the deeper sequential sections (Fig. 6D-K). Instead, different rings of cells appeared and disappeared. These rings resembled those found around the clusters of tracheary elements shown in Fig. 3J. In Fig. 6D-J and Supplementary Movie S1, it can be seen that some of these rings converge and diverge along the callus. 

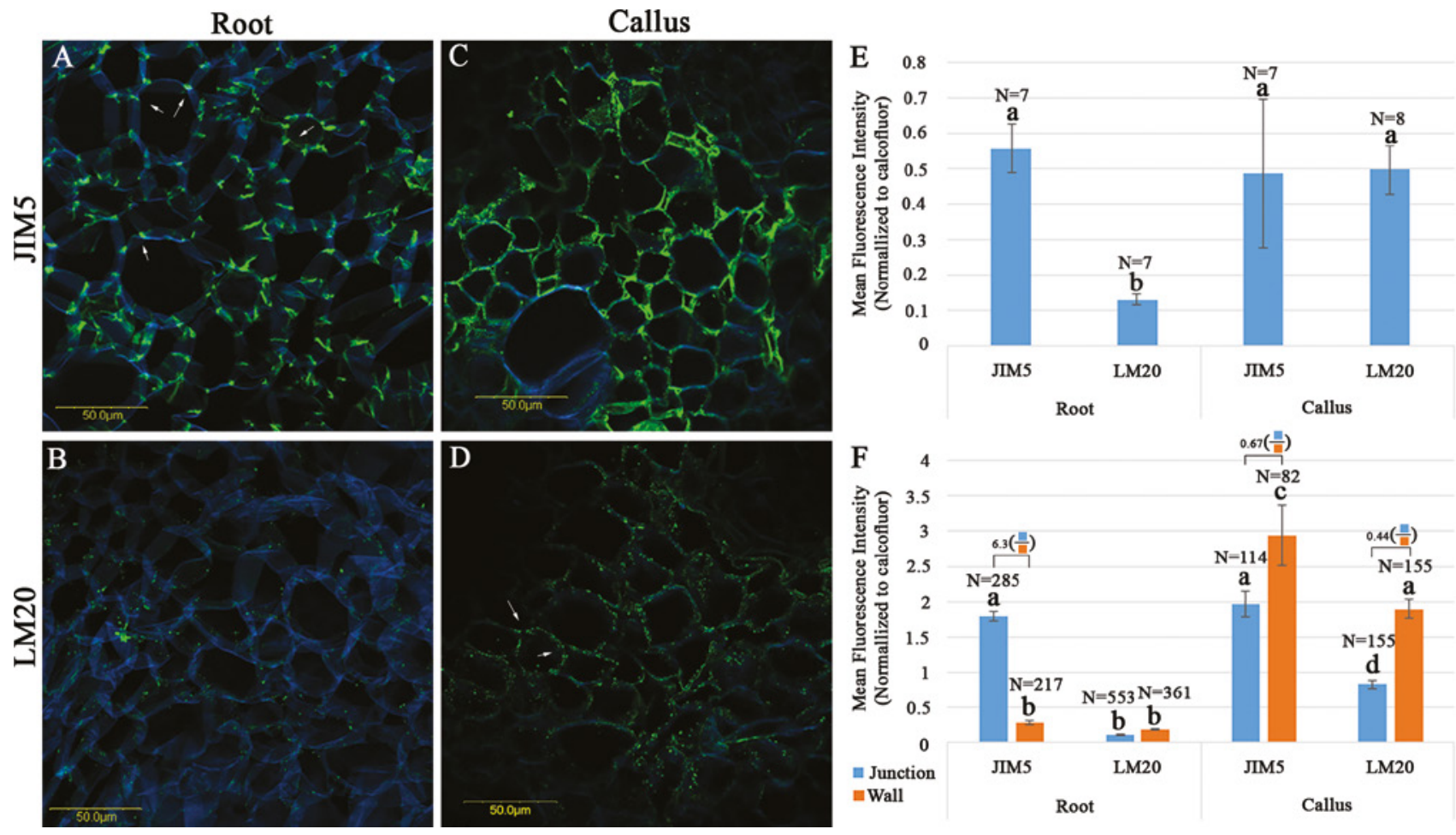

Figure 5. Immunostaining of E. brachyphylla root and callus sections for pectin isoforms. JIM5, antibody against de-methylesterified pectin; LM20, antibody against methylesterified pectin. $(A, B)$ Representative stained transverse sections of a root. (C,D) Representative stained transverse sections of callus. $(A, C)$ Samples stained with JIM5. Arrows in A show stain in three way junctions. (B,D) Samples stained with LM20. Arrows in D show three way junction devoid of stain. (E) Quantification of immunostaining normalized to calcofluor fluorescence in 7-8 independent fields (N). (F) Comparison of the normalized fluorescence intensity of the three-way junctions to that of the cell circumference. ( $\mathrm{N}=$ number of $\mathrm{ROI}$. Small rectangles above the bars show the ratio between them; $\mathrm{t}$-test, $\mathrm{p}$-value $<0.05)$.

Eventually, one of these rings of cells developed into a coherent root vasculature system with constant tissue arrangement along the sections (Fig. 6K-O), that gradually disengaged from the callus. The transition from Fig. $6 \mathrm{M}$ to $6 \mathrm{~N}$ shows the actual separation of the root tissue from the callus. Taken together, a root was seen to differentiate directly from the callus.

\section{Discussion}

The lack of food sources for honeybees toward the end of the summer and autumn until early winter led our research into AR formation. At first we selected two excellent trees exhibiting high flowering intensity and nectar production as well as strong attractiveness to honeybees during the desired season. We managed to overcome the difficulties involved in rooting mature trees and created a significant number of mother plants for further propagation and plantation. As expected the two Eucalyptus species responded differently to the rooting treatments applied (Vilasboa et al. 2018). The rooting rate of cuttings from E. brachyphylla was particularly surprising (Fig. 2) because previously, we had found that other clones of this species lose their rooting ability at the age of 7 months (Levy et al. 2014). In this respect, it should be emphasized that $E$. brachyphylla is a hybrid of $E$. kruseana and $E$. loxophleba (Grayling and Brooker, 1996) and $E \times$ trabutii is a hybrid of E. camaldulensis and E. botryoides (Chippendale, 1988). Therefore, genetic variability is expected within hybrids tree populations. The influence of genetic background on AR formation is known in the Eucalyptus genus (Vilasboa et al. 2018) as well as in other tree species (Legue et al. 2014; Panetsos et al. 1994).

During the propagation process, we noticed the striking phenomenon of cylindrical branched callus formation and the emergence of roots from them. This led us to explore the tissue anatomy and cell biology underlying these observations. Below we discuss our six main findings about cell and tissue organization in ARs versus callus. 


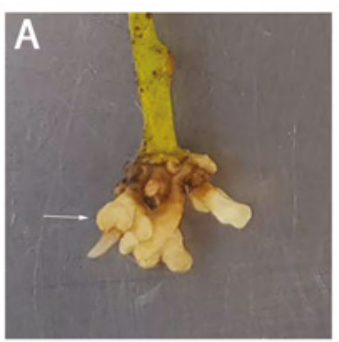

$\mathrm{F}$
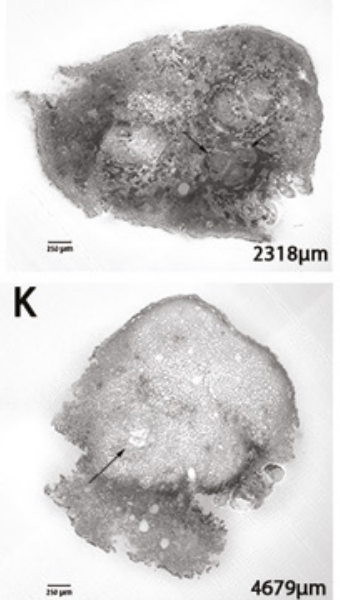

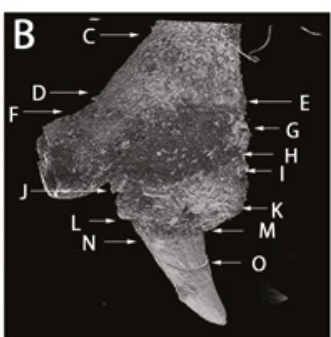

G

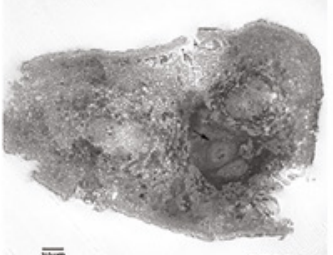

$\mathrm{H}$

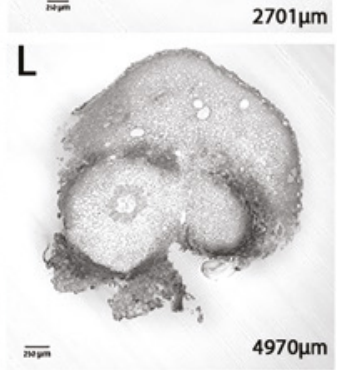

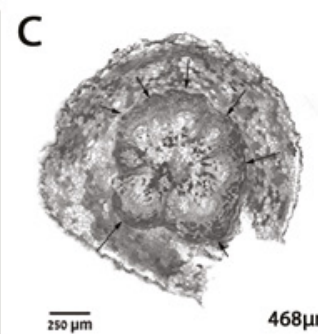

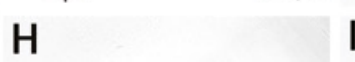

D

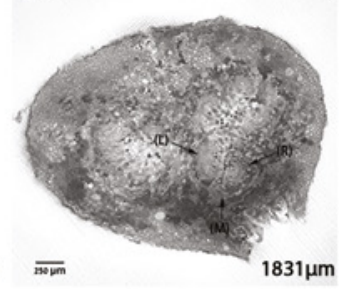

I

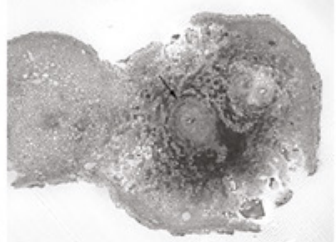

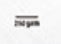

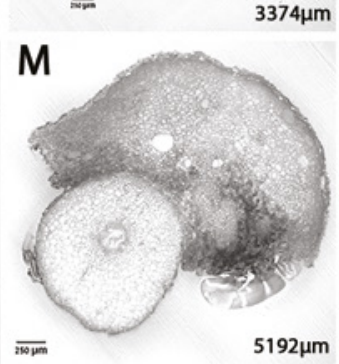

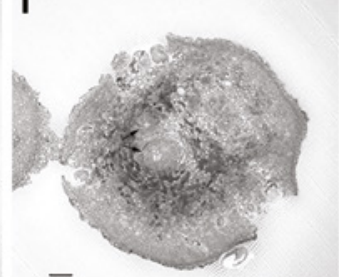

$\overline{m i n}$

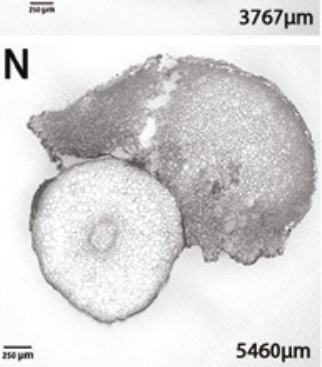

$\mathrm{E}$

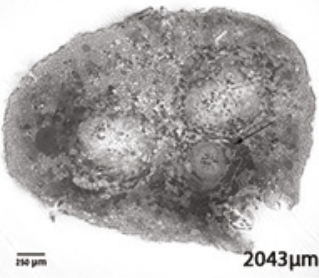

J

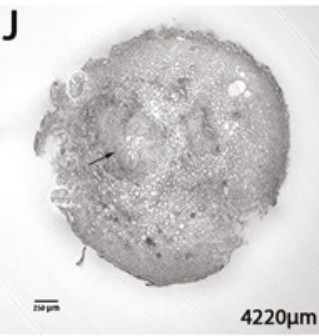

0

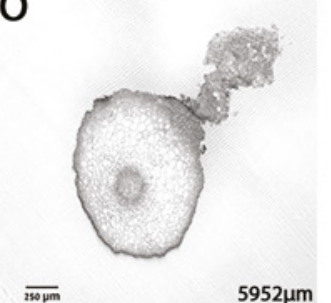

Figure 6. HREM imaging of a root-forming callus. (A) A callus from which a root is emerging (arrow). (B) A 3D model based on HREM sections. Letters refer to the depth of the sections in $\mathrm{C}-\mathrm{O}$. (C-I) These sections represent the dynamic cell changes within the callus. The diverging and converging rings probably represent tracheary zones (arrows). (J-L) Gradual transition from a chaotic tissue form to roottissue organization. (M-O) Emergence of the root from the callus. Numbers in the right bottom corner of each image are the section's depth. Scale bars are $250 \mu \mathrm{m}$.

(i) When roots and callus exhibiting a cylindrical shape were dissected longitudinally down the middle and stained for cellulose and lignin, cell organization and staining differed between the two tissues. Whereas in the root, cells with different function stained differently, in the callus, almost all cells looked similar and were stained to more or less the same extent for cellulose and lignin. No meristem-like domain was found in the several dozens of callus tips examined. Accordingly, the cylindrical callus was much shorter than the root and its full length was limited to 10-15 mm (Fig. 2D).

(ii) The length differences between callus and roots could be at least partially explained by the presence of elongated epidermal cells in the roots with cellulose microfibrils oriented perpendicular to the growth axis, as has been described for numerous plants (Szymanski and Cosgrove 2009). No such organization was observed in the callus. Instead, callus outer-layer cells showed isotropic growth or random orientation with no coherent polar growth and no particular microfibril orientation resolved by the calcofluor stain, thus forming a pattern that does not support a polar and coherent elongation. In the callus cells, we observed gaps or pit fields in the calcofluor stain which were reminiscent of the pits between cellulose microfibrils found in the Arabidopsis rootdivision zone (Sugimoto et al. 2000) and shoot apical meristem (Sampathkumar et al. 2019). Of note, callus cells developed from cuttings have a high rate of cell division (Greenwood et al. 2001), similar to meristematic cells. Despite their meristem-like features, callus cells were more strongly stained with cell-wall dyes than the cells in the root meristem, suggesting thicker cell walls. How a group of meristematic cells acquires a cylindrical shape has yet to be determined. Unorganized microfibrils can be found in cells at different developmental stages, for example, in shoot apical meristem cells (Sampathkumar et al. 2019), in Arabidopsis root cells after elongation ceases (Sugimoto et al. 2000), and after pharmacological 
(Himmelspach et al. 2003) or genetic (Desnos et al. 1996; Fagard et al. 2000; Williamson et al. 2001) inhibition of cellulose synthesis or after pharmacological (Baskin et al. 2004) or genetic (Bichet et al. 2001; Pastuglia et al. 2006; Whittington et al. 2001) disruption of microtubules. Each of these scenarios (unorganized microtubules or microfibrils) is conceivable in the callus cells developed from the Eucalyptus cuttings, shown in particular in Fig. 4B. Improper microtubule organization and cellulose synthesis have been previously shown to affect AR formation (Abu-Abied et al. $2014,2015 a, 2015 b)$. Of note, if indeed cellulose synthesis is reduced in callus cells, it might lead to compensatory lignification (Cano-Delgado et al. 2003; Hamann et al. 2009), which could underlie the findings shown in Fig. $3 \mathrm{C}, \mathrm{J}, \mathrm{K}, \mathrm{L}$ of higher lignification than in the root meristem (Fig. 3B).

(iii) The swollen cells found at the edge of some sections (Fig. 3E) could be epidermal cells or root hairs. Swollen epidermal cells with thin cell walls have been found, for example, in the prc1 mutant, with a mutation in the cellulose synthase subunit CESA6 (Desnos et al. 1996; Fagard et al. 2000), again suggesting reduced cellulose synthesis. Alternatively, these cells might represent short swollen root hairs. Swollen root hairs are commonly seen in mutants of actin (Grierson and Ketalaar 2004) or Rho of plants (ROP) GTPases (Bloch et al. 2005; Molendijk et al. 2001), which regulate both actin and microtubules (Craddock et al. 2012). In addition, a mutation in the cellwall protein leucine-rich repeat extensin 1 (LRX1) resulted in swollen root hairs (Diet et al. 2006). Interestingly, swollen root hairs in the Irx 1 mutant were repressed by the rol1 mutation affecting pectin synthesis (Diet et al. 2006).

(iv) When callus and root cells were stained for pectin using antibodies that distinguish methylesterified from de-methylesterified pectin, significant differences were found. Whereas demethylesterified pectin was mainly concentrated in three-way junctions between the root cells, it was distributed throughout the callus cell walls. In addition, higher fluorescence staining corresponding to methylesterified pectin was found in callus cells vs. root cells. Pectin and pectin methylesterification are regulated at various levels (Peaucelle et al. 2015; Wolf et al. 2012) and can affect cell-wall rigidity, cell expansion, and organ development in different ways (Peaucelle et al. 2012; Peaucelle et al. 2011; Voxeur and Hofte 2016). Differential pectin methylesterification has been shown in callus from cork oak (Quercus suber) formed in tissue culture (Pérez-Pérez et al. 2019). The proembryogenic cells were rich in methylesterified pectin, while the differentiated cells of the embryo were rich in de-methylesterified pectin (Pérez-Pérez et al. 2019). Another study compared pectin status in the tightly packed embryogenic callus to that in the loosely packed non-embryogenic callus of carrot (Daucus carota subsp. sativus) (Iwai et al. 1999). The rationale was that since pectin in the middle lamella is a major glue for cells, its form can influence the rate of cell-cell adhesion in the callus. Pectin was stained with Ruthenium red which bound primarily to demethylesterified pectin (Iwai et al. 1999). While the tightly packed cells of the embryogenic callus were mainly stained at three-way junctions, the cells in non-embryogenic callus were stained all around their cell walls. Thus, despite the high levels of pectin ready to form $\mathrm{Ca}^{2+}$ bridges might increase the cell-cell adhesion, more and larger gaps were found between these cells. This led to the conclusion that there was no correlation between the rate of pectin de-methylesterification and the gaps between the cells in the carrot callus (Iwai et al. 1999). However it is known that the consequences of demethyl esterification can be cell wall loosening when de-esterified pectin is subsequently cut by pectolytic enzymes (Pelloux et al. 2007; Xiao et al. 2014). Taken together, it is difficult to identify any general trend; it seems that context dependent, temporal and spatial changes of pectin methylesterification should be determined at higher resolution to find correlations with cell-cell adhesion and differentiation.

(v) Differentiation of tracheary element clusters was found in the inner cell layers of the callus (Fig. $3 \mathrm{H}-$ J). These clusters contained individual differentiated cells positioned in different orientations with respect to each other, i.e., not forming a continuous pipe. Some of these clusters were surrounded by several layers of cells forming a circumferential ring (Fig. 3J). These rings were also resolved by HREM (Fig. 6E-K arrows). Supplementary Movie S1 shows that these rings can disappear, split or 
converge along the callus, again exemplifying the discontinuous nature of this vasculature-like tissue. Clusters of differentiated tracheary elements inside callus tissue have been previously described (Wilson et al. 1991). In that study, it was postulated that these clusters are formed in the inner layers due to an inside/out gradient of Indole-3-acetic acid (IAA). Auxin canalization has been shown to lead to vasculature differentiation and reconstruction after wounding (Sachs 1991). Furthermore, non-oriented tracheary elements have been shown to be the result of counteracting flows of auxin (Lev-Yadun and Aloni 1990; Sachs and Cohen 1982), suggesting a chaotic network of auxin flow inside the callus.

(vi) The most striking, albeit rare, finding was the differentiation of the chaotic callus tissue into a root with orchestrated cells and functioning tissues. In this respect, it is interesting to note that in Arabidopsis, it was found that callus formed from different non-root tissues laid on callus-inducing medium expresses root-specific genes (Sugimoto et al. 2010), whereas callus formed from wounded tissues does not (lkeuchi et al. 2013). Changes in hormone balance, cell wall composition, gene expression, etc., in the Eucalyptus callus which lead to the sudden formation of a root will be the subject of our future research.

Accumulating data suggest that cell-wall properties influence the formation of lateral and adventitious roots (Duman et al. 2019, this issue). The current work raises the possibility that the high rate of callus formation in cuttings from mature trees, in contrast to juvenile trees, following root induction with IBA is a result of differences in, among other things, cell-wall properties.

The term callus originates from the Latin word callōsus, which means hard skin. In plants, it refers to both clusters of cells formed on callus-inducing media, preferentially from young tissues, and clusters of cells formed following wounding and root induction with auxin. Obviously, there are major differences between these two tissues which might warrant a distinct definition.

Finally, the advantage of a clonal plantation of elite trees for bees will be verified once their flower intensity and robustness are compared to other trees germinated from seeds of the same two selected species. This verification will be obtained in the coming years.

\section{Acknowledgements}

This work was financed by Keren Kayemet Lelsrael (KKL) grant no. 10-03-006. We thank Prof emeritus Dan Eisikowitch from the Tel-Aviv University for the inspiration to this work.

\section{Supplementary material}

Supplementary material is available online at: https://doi.org/10.6084/m9.figshare.9896507

\section{References}

Abu-Abied, M., Mordehaev, I., Sunil Kumar, G.B., Ophir, R., Wasteneys, G.O., Sadot, E. (2015a). Analysis of MicrotubuleAssociated-Proteins during IBA-Mediated Adventitious Root Induction Reveals KATANIN Dependent and Independent Alterations of Expression Patterns. PLoS One. 10: e0143828.

Abu-Abied, M., Rogovoy Stelmakh, O., Mordehaev, I., Grumberg, M., Elbaum, R., Wasteneys, G.O., Sadot, E. (2015b). Dissecting the contribution of microtubule behaviour in adventitious root induction. J. Exp. Bot. 66(9): 2813-2824.

Abu-Abied, M., Szwerdszarf, D., Mordehaev, I., Levy, A., Stelmakh, O.R., Belausov, E., Yaniv, Y., Uliel, S., Katzenellenbogen, M., Riov, J., Ophir, R., Sadot, E. (2012). Microarray analysis revealed upregulation of nitrate reductase in juvenile cuttings of Eucalyptus grandis, which correlated with increased nitric oxide production and adventitious root formation. Plant $J$. 71: 787-799.

Abu-Abied, M., Szwerdszarf, D., Mordehaev, I., Yaniv, Y., Levinkron, S., Rubinstein, M., Riov, J., Ophir, R., Sadot, E. (2014). Gene expression profiling in juvenile and mature cuttings of Eucalyptus grandis reveals the importance of microtubule remodeling during adventitious root formation. BMC Genomics. 15: 826 .

Baskin, T.I., Beemster, G.T., Judy-March, J.E., Marga, F. (2004). Disorganization of cortical microtubules stimulates tangential expansion and reduces the uniformity of cellulose microfibril alignment among cells in the root of Arabidopsis. Plant Physiol. 135: 2279-2290.

Bichet, A., Desnos, T., Turner, S., Grandjean, O., Hofte, H. (2001). BOTERO1 is required for normal orientation of cortical microtubules and anisotropic cell expansion in Arabidopsis. Plant J. 25: 137-148.

Bloch, D., Lavy, M., Efrat, Y., Efroni, I., Bracha-Drori, K., Abu-Abied, M., Sadot, E., Yalovsky, S. (2005). Ectopic expression of an activated RAC in Arabidopsis disrupts membrane cycling. Mol. Biol. Cell. 16: 1913-1927.

Cané-Retamales, C., Mora, F., Vargas-Reeve, F., Perret, S., Contreras-Soto, R. (2011). Bayesian threshold analysis of breeding values, genetic correlation and heritability of flowering intensity in Eucalyptus cladocalyx under arid conditions. Euphytica. 178: 177-183.

Cano-Delgado, A., Penfield, S., Smith, C., Catley, M., Bevan, M. (2003). Reduced cellulose synthesis invokes lignification 
and defense responses in Arabidopsis thaliana. Plant J. 34: 351-362.

Chippendale, G.M. (1988). Flora of Australia Volume 19, Myrtaceae, Eucalyptus, Angophora. Ed. George, A. S., Australian Government Publishing Service, Canberra.

Cosgrove, D.J. (2016). Plant cell wall extensibility: connecting plant cell growth with cell wall structure, mechanics, and the action of wall-modifying enzymes. J. Exp. Bot. 67: 463-476.

Craddock, C., Lavagi, I., Yang, Z. (2012). New insights into Rho signaling from plant ROP/Rac GTPases. Trends Cell Biol. 22: 492-501.

Davis, A., R. (1997). Influence of floral visitation on nectar-sugar composition and nectary surface changes in Eucalyptus. Apidologie. 28: 27-42.

Desnos, T., Orbovic, V., Bellini, C., Kronenberger, J., Caboche, M., Traas, J., Hofte, H. (1996). Procuste1 mutants identify two distinct genetic pathways controlling hypocotyl cell elongation, respectively in dark- and light-grown Arabidopsis seedlings. Development. 122: 683-693.

Diaz-Sala, C. (2014). Direct reprogramming of adult somatic cells toward adventitious root formation in forest tree species: the effect of the juvenile-adult transition. Front. Plant Sci. 5: 310.

Diet, A., Link, B., Seifert, G.J., Schellenberg, B., Wagner, U., Pauly, M., Reiter, W.D., Ringli, C. (2006). The Arabidopsis root hair cell wall formation mutant Irx1 is suppressed by mutations in the RHM1 gene encoding a UDP-L-rhamnose synthase. Plant Cell. 18: 1630-1641.

Fagard, M., Desnos, T., Desprez, T., Goubet, F., Refregier, G., Mouille, G., McCann, M., Rayon, C., Vernhettes, S., Hofte, H. (2000). PROCUSTE1 encodes a cellulose synthase required for normal cell elongation specifically in roots and darkgrown hypocotyls of Arabidopsis. Plant Cell. 12: 2409-2424.

Grayling, P.M., Brooker, M.I.H. (1996). Evidence for the Identity of the Hybrid Eucalyptus 'brachyphylla' (Myrtaceae) from Morphology and Essential-oil Composition. Aust. J. Bot. 44: 1-13.

Greenwood, M.S., Cui, X., Xu, F. (2001). Response to auxin changes during maturation-related loss of adventitious rooting competence in loblolly pine (Pinus taeda) stem cuttings. Physiol. Plant. 111: 373-380.

Grierson, C., Ketalaar, K. 2004. The cytoskeleton and plant cell morphogenesis: development of root hairs. In: PJ Hussey, ed. The Plant and Cytoskeleton in Cell Differentiation and Development, Vol. 10. Oxford.uk: Blackwell Publishing, 205-239.

Hackett, W.P. (1985). Juvenility, maturation and rejuvenation in woody plants. Hort. Rev. 7: 109-155.

Hamann, T., Bennett, M., Mansfield, J., Somerville, C. (2009). Identification of cell-wall stress as a hexose-dependent and osmosensitive regulator of plant responses. Plant J. 57: 1015-1026.

Himmelspach, R., Williamson, R.E., Wasteneys, G.O. (2003). Cellulose microfibril alignment recovers from DCB-induced disruption despite microtubule disorganization. Plant J. 36: 565-575.

Horskins, K., Turner, V.B. (1999). Resource use and foraging patterns of honeybees, Apis mellifera, and native insects on flowers of Eucalyptus costata. Aus. J. of Ecology. 24: 221-227.
Ikeuchi, M., Sugimoto, K., Iwase, A. (2013). Plant callus: mechanisms of induction and repression. Plant Cell. 25: 3159-3173.

Iwai, H., Kikuchi, A., Kobayashi, T., Kamada, H., Satoh, S. (1999). High levels of non-methylesterified pectins and low levels of peripherally located pectins in loosely attached non-embryogenic callus of carrot. Plant Cell Reports. 18: 561-566.

Izhaki, A., Alvarez, J.P., Cinnamon, Y., Genin, O., Liberman-Aloni, R., Eyal, Y. (2018). The Tomato Blade on Petiole and Terminating Flower Regulate Leaf Axil Patterning Along the ProximalDistal Axes. Front. in Plant Sci. 9.

Johnson, E.D. (1926). A comparison of the juvenile and adult leaves of Eucalyptus globulus New Phytologist. 25: 202-212.

Keasar, T., Shmida, A. (2009). An evaluation of Israeli forestry trees and shrubs as potential forage plants for bees. Isr. J. Plant Sci. 57: 49-64.

Knox, J.P., Linstead, P.J., King, J., Cooper, C., Roberts, K. (1990). Pectin esterification is spatially regulated both within cell walls and between developing tissues of root apices. Planta. 181: 512-521.

Kurihara, D., Mizuta, Y., Sato, Y., Higashiyama, T. (2015). ClearSee: a rapid optical clearing reagent for whole-plant fluorescence imaging. Development. 142: 4168-4179.

Legue, V., Rigal, A., Bhalerao, R.P. (2014). Adventitious root formation in tree species: involvement of transcription factors. Physiol. Plant. 151: 192-198.

Lev-Yadun, S., Aloni, R. (1990). Vascular differentiation in branch junctions of trees: circular patterns and functional significance. Trees 4: 49-54.

Levy, A., Szwerdszarf, D., Abu-Abied, M., Mordehaev, I., Yaniv, Y., Riov, J., Arazi, T., Sadot, E. (2014). Profiling microRNAs in Eucalyptus grandis reveals no mutual relationship between alterations in miR156 and miR172 expression and adventitious root induction during development. BMC Genomics. 15: 524.

Li, C., Wang, K. (2003). Differences in drought responses of three contrasting Eucalyptus microtheca F. Muell. populations. For. Ecol. Manage. 179: 377-385.

Lupo,A.,Eisikowitch,D.(1990).Eucalyptuserythrocoris:asourceof nectarand pollenforhoneybeesinlsrael.Apidologie.21:25-33.

Molendijk, A.J., Bischoff, F., Rajendrakumar, C.S., Friml, J., Braun, M., Gilroy, S., Palme, K. (2001). Arabidopsis thaliana Rop GTPases are localized to tips of root hairs and control polar growth. EMBO J. 20: 2779-2788.

Moncur, M., Boland, D. (1989). Floral Morphology of Eucalyptus melliodora A Cunn. ex Schau. And Comparisons With Other Eucalypt Species. . Aus. J. of Botany. 37: 125-135.

Panetsos, K., Scaltsoyiannes, A., Alizoti, P. (1994). Effect of genotype and cutting type on the vegetative propagation of the pine hybrid (Pinus brutia (Ten.) $\times$ Pinus halepensis (Mill.)). Annales des Sciences Forestières. Ann. Sci For. 51: 447-454.

Pastuglia, M., Azimzadeh, J., Goussot, M., Camilleri, C., Belcram, K., Evrard, J.L., Schmit, A.C., Guerche, P., Bouchez, D. (2006). Gamma-tubulin is essential for microtubule organization and development in Arabidopsis. Plant Cell. 18: 1412-1425.

Peaucelle, A., Braybrook, S., Hofte, H. (2012). Cell wall mechanics and growth control in plants: the role of pectins revisited. Front. Plant Sci. 3: 121. 
Peaucelle, A., Braybrook, S.A., Le Guillou, L., Bron, E., Kuhlemeier, C., Hofte, H. (2011). Pectin-induced changes in cell wall mechanics underlie organ initiation in Arabidopsis. Curr. Biol. 21: 1720-1726.

Peaucelle, A., Wightman, R., Hofte, H. (2015). The Control of Growth Symmetry Breaking in the Arabidopsis Hypocotyl. Curr. Biol. 25: 1746-1752.

Pelloux, J., Rusterucci, C., Mellerowicz, E.J. (2007). New insights into pectin methylesterase structure and function. Trends Plant Sci. 12: 267-277.

Pérez-Pérez, Y., Carneros, E., Berenguer, E., Solís, M.-T., Bárány, I., Pintos, B., Gómez-Garay, A., Risueño, M.C., Testillano, P.S. (2019). Pectin De-methylesterification and AGP Increase Promote Cell Wall Remodeling and Are Required During Somatic Embryogenesis of Quercus suber. Front. Plant Sci. 9: 1915

Poethig, R.S. (1990). Phase change and the regulation of shoot morphogenesis in plants. Science. 250: 923-930.

Poethig, R.S. (2010). The past, present, and future of vegetative phase change. Plant Physiol. 154: 541-544.

Riov, J., Szwerdszarf, D., Abu-Abied, M., Sadot, E. (2013). The molecular mechanisms involved in adventitious root formation. In: Plant Roots: The Hidden Half 4th ed, Eshel, A and Beeckman T, eds Taylor \& Francis pp. 11.11-11.14.

Sachs, T. (1991). Cell polarity and tissue patterning in plants. Development. 113: 83-93.

Sachs, T., Cohen, D. (1982). Circular Vessels and the Control of Vascular Differentiation in Plants. Differentiation. 21: $22-22-26$.

Sampathkumar, A., Peaucelle, A., Fujita, M., Schuster, C., Persson, S., Wasteneys, G.O., Meyerowitz, E.M. (2019). Primary wall cellulose synthase regulates shoot apical meristem mechanics and growth. Development. 146(10) E-pub dev179036 doi: 10.1242/dev.179036

Schindelin, J., Arganda-Carreras, I., Frise, E., Kaynig, V., Longair, M., Pietzsch, T., Preibisch, S., Rueden, C., Saalfeld, S., Schmid, B., Tinevez, J.Y., White, D.J., Hartenstein, V., Eliceiri, K., Tomancak, P., Cardona, A. (2012). Fiji: an open-source platform for biological-image analysis. Nat. Methods. 9: 676-682.

Somervill, D.C. (2001). Nutritional Value of Bee Collected Pollens. Rural Industries Research and Development Corporation.
Sugimoto, K., Jiao, Y., Meyerowitz, E.M. (2010). Arabidopsis regeneration from multiple tissues occurs via a root development pathway. Dev. Cell. 18: 463-471.

Sugimoto, K., Williamson, R.E., Wasteneys, G.O. (2000). New techniques enable comparative analysis of microtubule orientation, wall texture, and growth rate in intact roots of Arabidopsis. Plant Physiol. 124: 1493-1506.

Szymanski, D.B., Cosgrove, D.J. (2009). Dynamic coordination of cytoskeletal and cell wall systems during plant cell morphogenesis. Curr. Biol. 19: R800-811.

Ursache, R., Andersen, T.G., Marhavy, P., Geldner, N. (2018). A protocol for combining fluorescent proteins with histological stains for diverse cell wall components. Plant J. 93: 399-412.

Verhertbruggen, Y., Marcus, S.E., Haeger, A., Ordaz-Ortiz, J.J., Knox, J.P. (2009). An extended set of monoclonal antibodies to pectic homogalacturonan. Carbohydr. Res. 344: 1858-1862.

Vilasboa, J., Da Costa, C.T., Fett-Neto, A.G. (2018). Rooting of eucalypt cuttings as a problem-solving oriented model in plant biology. Prog Biophys Mol Biol.

Voxeur, A., Hofte, H. (2016). Cell wall integrity signaling in plants: "To grow or not to grow that's the question". Glycobiology. 26: 950-960.

Whittington, A.T., Vugrek, O., Wei, K.J., Hasenbein, N.G., Sugimoto, K., Rashbrooke, M.C., Wasteneys, G.O. (2001). MOR1 is essential for organizing cortical microtubules in plants. Nature. 411: 610-613.

Williamson, R.E., Burn, J.E., Birch, R., Baskin, T.I., Arioli, T., Betzner, A.S., Cork, A. (2001). Morphology of rsw1, a cellulosedeficient mutant of Arabidopsis thaliana. Protoplasma. 215: 116-127.

Wilson, J.W., Wilson, P.M.W., Walker, E.S. (1991). Patterns of Tracheary Differentiation in Lettuce Pith Explants: Positional Control and Temperature Effects. Ann. Bot. 68: 109-128.

Wolf, S., Hematy, K., Hofte, H. (2012). Growth control and cell wall signaling in plants. Annu. Rev. Plant Biol. 63: 381-407.

Xiao, C., Somerville, C., Anderson, C.T. (2014). POLYGALACTURONASE INVOLVED IN EXPANSION1 functions in cell elongation and flower development in Arabidopsis. Plant Cell. 26: 1018-1035. 